\title{
Contemplar a Dios sin imágenes. La imagen en los tratados de meditación en la Primera Edad Moderna
}

\author{
Iveta Nakládalová \\ Universitat Autònoma de Barcelona \\ ivetanak@gmail.com
}

Recepción: 21/09/2015, Aceptación: 28/09/2015, Publicación: 22/12/2015

\begin{abstract}
Resumen
La presencia y la función de la imagen en la literatura espiritual altomoderna constituye un problema de primer orden, en el que convergen múltiples aspectos -iconográficos, históricos y sociales, pero también teológicos y doctrinales. La imagen es objeto de las controversias religiosas más significativas de la Primera Edad Moderna, e interviene, en gran medida, en la profunda fractura doctrinal en la Europa de la segunda mitad del siglo XVI. El presente estudio analiza el papel de la imagen en los tratados de meditación de los siglos XVI y XVII. Revisa las premisas doctrinales que sustentan la teoría de la imagen devota; expone los debates teologales acerca de su uso legítimo y apropiado por parte de los creyentes, y el papel de la figura material en las prácticas meditativas. Por último, explora la imagen como vehículo de la censura difusa, esto es, considera su actuación en el sutil - pero por ello no menos eficaz-disciplinamiento doctrinal de los fieles.
\end{abstract}

\section{Palabras clave}

meditación; bildmeditation; tratados de oración y meditación; imagen; figura; censura; censura difusa; disciplinamiento; Primera Edad Moderna; conocimiento de Dios; visibilia; invisibilia; imaginación

\begin{abstract}
The role and the use of the image constitutes an extraordinarily interesting topic in the analysis of Early Modern devotional literature, in which numerous aspects (iconographical, historical, social, theological and doctrinal) are to be considered. The image, in fact, represents a key issue in Early Modern religious debates, and plays a significant role in the Reformation and Counter Reformation fracture in the second half of the $16^{\text {th }}$ century. The present study assesses the role of image in the $16^{\text {th }}$ and $17^{\text {th }}$ century meditation treatises
\end{abstract}


(mainly of Hispanic and Italian origin). It examines the doctrinal premises that sustain the Early Modern theory of religious image, surveys the contemporary debates concerning its legitimate use, and explores the role of the material image (figura) in meditative practice. Finally, it assesses the image as an agent of soft censorship, in other words, it explores its function in the doctrinal disciplining of the devotees.

\section{Keywords}

meditation; bildmeditation; treatises on meditation and prayer; image; figura; censorship; soft censorship; doctrinal disciplining; Early Modern devotional literature; knowledge of God; visibilia; invisibilia; imagination

La presencia y la función de la imagen en la literatura espiritual altomoderna constituye un problema de primer orden, en el que convergen múltiples aspectos —iconográficos, históricos y sociales, pero también teológicos y doctrinales. La imagen es objeto de las controversias religiosas más significativas de la Primera Edad Moderna, e interviene, en gran medida, en la profunda fractura doctrinal en la Europa de la segunda mitad del siglo xvi. Pensemos, por ejemplo, en el debate sobre la idolatría, que marcó uno de los enfrentamientos más notables entre las posiciones de la Reforma y la postura contrarreformista. Es la imagen (o la figura en general, que incluye pinturas, estatuas, estampas y efigies) y su aprehensión la que, en cuanto a la veneración de los ídolos, delimita la sutil e inquietante frontera entre lo sagrado y lo profano. ${ }^{1}$

Más aún, el problema de la adoración excesiva o inapropiada de la imagen piadosa está relacionado con la controversia acerca de la representación artística de lo sagrado, esto es, subyace en todas las polémicas en torno al ars sacra, y predispone también las premisas teológicas en torno a la imagen de Dios y la apropiación de lo invisible a través de lo visible. ${ }^{2}$

1. Afirma Pierre Civil (1995: 8) que, en la Primera Edad Moderna, la imagen se sitúa en el «cruce entre los textos teológicos, la formación catequista y los sentimientos de fervor religioso", y que la cultura visual representa «un lugar de contacto privilegiado entre la espiritualidad y las relaciones de poder», constituyendo la «expresión de un imaginario inaprensible». Desde esta perspectiva, la imagen va más allá de un simple artificio narrativo, y no sorprende que el uso correcto de las imágenes, especialmente por parte de los iletrados, deviniese en uno de los puntos más polémicos en los debates eclesiásticos.

2. Cf. Civil (1995: 123). 
Desde una perspectiva más amplia, en la que confluyen la figura material y la representación mental, la cuestión de la imagen en los tratados espirituales está condicionada por el modelo epistémico del alma, por la conceptualización altomoderna de las funciones psíquicas. La facultad responsable de generar imágenes mentales - la imaginación - forma parte, junto con el entendimiento y la voluntad, de la tríada de las potencias del alma. Cabe destacar la condición extraordinariamente ambigua de esta facultad en la tratadística contemporánea: la imaginación entrańa un peligro moral porque, como explica Luis de Puente en sus Meditaciones, «las imágenes y figuras de las cosas visibles [...] inquietan la imaginación y la memoria con distracciones y vagueaciones; y alborotan los apetitos con el desconcierto de las pasiones, y turban el coraçón echándonos fuera dél». Los sentidos, entre ellos la vista, se asemejan a "puertas y ventanas», por las que entran los pecados. "Mi ojo me roba mi alma», sentencia Luis de Puente, porque «me roba la atención, el pensamiento y la afición, haziendo que el alma no esté tanto dentro de mí, cuanto fuera, en la cosa que piensa y ama». ${ }^{3}$

En efecto, la presencia o, por el contrario, la anulación o suspensión de las potencias del alma durante las prácticas devocionales representa uno de los puntos doctrinales más polémicos entre los defensores de la devoción tradicional, por un lado, y los representantes de las corrientes espirituales heterodoxas, por el otro. Los seguidores de la doctrina del recogimiento (que en sus formulaciones extremas desembocará en las corrientes del quietismo) pretenden fundir incondicionalmente la voluntad propia con la divina, vaciando el alma y la mente para poder contemplar la esencia suprema. Las reinterpretaciones más radicales de estos modelos espirituales (como, por ejemplo, el alumbradismo) buscan una relación directa con Dios, sin ataduras, prescindiendo por completo de rituales e imágenes. ${ }^{4}$ Ese es el caso, según se desprende del auto de su proceso inquisi-

3. Luis de Puente (1609: 193-4).

4. Según Serés (2003: 26), no obstante, en el caso del quietismo, la fusión de la voluntad propia con la divina no implica la suspensión de las demás facultades del alma (entre ellas la imaginación), por lo menos en el contexto de la contemplación iluminativa: «[...] quietud, originada por la intuición de la presencia de Dios: consiste en fundir la voluntad propia con la divina, no así el entendimiento, la memoria y la imaginación». Las posturas teologales son muy ambiguas en este punto. El trinitario Diego de la Madre de Dios (1713: 196) afirma en su Arte mistica que las imágenes (en cuanto figuras materiales) pueden contribuir al deliquio, entendido como la suspensión de los sentidos y de las potencias y facultades del alma («deliquio de el alma sucede, quando con la fuerça de la luz, y comunicación divina, recoge Dios al alma de repente, o poco a poco; $\mathrm{y}$ de tal suerte atrae à sì las potencias, y facultades de ella, que queda el cuerpo destituido de el vso de los sentidos, y operaciones exteriores, y sensibles. Y entonces (dize Santa Theresa) comiença el Señor a mostrar a la alma los tesoros de su Reyno, que la tiene aparejados: y para que los sentidos no sean obstáculo a esta comunicación, manda que se cierren»). Pero el deliquio debe ser evitado, advierte Diego de la Madre de Dios, porque «suelen suceder a los que aun no tienen el espíritu de el todo purgado, y bien dispuesto para las cosas puramente espirituales. Y assí se han de procurar evitar, porque pueden proceder de causa natural, como se dixo; o pueden ser causados por el enemigo, o porque pueden ser dañosos a la salud». El medio para evitarlos es, «lo primero, pedir 
torial, de Isabel de la Cruz, quien, acusada del alumbradismo, declara que «las imágenes eran los libros de los inferiores o ignorantes», y añade sarcásticamente que «bien se le estaba a aquél, o que bien le iban las cosas a aquél que tenía que acordarse de Dios por las imágenes». 5

Por el contrario, los defensores de actitudes menos radicales - tanto los representantes de la espiritualidad más tradicional como los adalides de las posiciones menos extremas de la nueva pietas - ${ }^{6}$ recomiendan la meditación sustentada en una imagen concreta. Así, Fray Juan de la Cruz, ${ }^{7}$ en su Diálogo sobre la necesidad de la oración vocal, censura las fórmulas espirituales que implican la total aniquilación de las potencias del alma y que requieren la anulación de la imaginación, para que el entendimiento se presente delante del Señor completamente desnudo y «desocupado de todas imágenes, memorias, cuidados, distracciones de cualesquiera cosas criadas». ${ }^{8}$ En su crítica, Fray Juan de la Cruz consiente la suspensión de las afecciones y de las preocupaciones terrenales, pero restringe la prohibición de las imágenes únicamente a las imaginaciones vanas y culpables, ${ }^{9}$ abogando por la meditación basada en

\begin{abstract}
a Dios, que los impida [...] lo segundo, que en la Oración se aparte de consideraciones, y figuras materiales; y para la Meditación se valga de el discurso, y de las razones [...]. Y si experimenta, que le suceden por mirar alguna imagen devota, o por hablar de el Amor de Dios [...] se abstenga de ellas por entonces: y procure, aun quando padeciere el deliquio, apartar el espiritu de la atención a las formas materiales, quanto la interior ocupación lo permitiere». Diego de la Madre de Dios (1713: 197), la cursiva es mía. La técnica ascética de la suspensión de la imaginación está presente también en el misticismo árabe y en el misticismo bizantino (ortodoxo) medieval, que pretende anular las potencias imaginativas, ya que «imagination [...] serves as bridge for the demons, over which these murderous miscreants cross and recross, commune and mix with the soul and make it a hive for many drones - the abode of barren and pasionate thoughts. [Therefore], keep your mind empty of colour, image, form, appearence, quality, and quantity». San Simeón, citado en Grunebaum [1964: 107].
\end{abstract}

5. Citado en Tausiet (2013: 80). Explica Pierre Civil (1995: 66) que algunas formas extremas del recogimiento franciscano (los cenáculos de beatas y los alumbrados) rechazan toda manifestación externa de la piedad, toda mediación material en el proceso de la unión con lo divino.

6. La autora es consciente del uso discutible de estas denominaciones excesivamente genéricas. En el contexto del presente estudio, se refieren a dos posiciones contrarias en relación con el uso de la imagen: una vinculada a la doctrina apostólica y teológica; la otra, sin ser heterodoxa, se aventura en consideraciones espirituales que pueden ser percibidas como cuestionables.

7. Nacido en Talavera de la Reina, en la década de 1490. Mira Gómez de Mercado (2012) reúne los escasos datos biográficos conservados sobre este fraile dominico.

8. Todo el pasaje sigue así: «Leo muchas veces aconsejado y amonestado con muchas palabras mil veces repetidas, que procuren los hombres con todo deseo, con todo estudio, con vehemente espíritu contemplar la majestad divina pura en sí misma, con entendimiento desnudo y desocupado de todas imágenes, memorias, cuidados, distracciones de cualesquiera cosas criadas. [...] Y por alcanzar esta alteza de contemplación suspire y anhele, y se despida y eche de sí todas imaginaciones y fantasías; asimismo, todos amores y aficiones y cuidados de las cosas criadas.» Fray Juan de la Cruz (1962: 349), apartado «Contra los que aconsejan que se procure contemplar a Dios sin imágenes y sin afecciones humanas».

9. «Porque ¿̨cómo los santos habían de enseñar que despidiesen los hombres todos los cuidados y afecciones y pensamientos extrańos de Dios, sabiendo que los que a nosotros tocan no podemos 
una imagen concreta, porque «la pretensión de contemplar a Dios sin imagen es contraria a la humildad». ${ }^{10}$

De otros testimonios análogos podemos inferir que los defensores de la piedad tradicional no rechazan del todo la suspensión de las potencias del alma, pero ésta debe reservarse exclusivamente a los devotos más experimentados en la fase de la contemplación. Al referir, supuestamente, las palabras de San Juan de la Cruz en su Subida del Monte Carmelo, «las almas que en la Oración no quieren salir de figuras y semejanzas particulares, se estorban» ${ }^{11}$ Antonio Arbiol en su guía espiritual titulada Desengaños misticos aclara que "esta sentencia es verdadera, en el estado de las almas de quien el Santo habla en este capítulo; pero si alguna persona la entendiese fuera de ese mismo estado, se engañaría; porque las figuras y semejanzas, muchas veces ayudan en la oración mental, para excitar santísimos afectos en las almas, principalmente quando se exercitan en piadosas meditaciones, antes de ser contemplativas». ${ }^{12}$ En efecto, la meditación se estable-

excusar [...]? Pero si esto que dije quisieron enseñar en sus tratados, convenía no usar de tan generales palabras y amonestaciones tan hincadas como usan, mas como los santos distintamente aconsejan que huyamos de las imaginaciones vanas y afecciones culpables, porque no entiendan los leyentes simples que aun las buenas aficiones y cuidados nos hemos de ajenar». Fray Juan de la Cruz (1962: 351).

10. Fray Juan de la Cruz (1962: 359). La argumentación de Juan de la Cruz remite al postulado aristotélico (acogido por la escolástica medieval) de que el entendimiento requiere nociones conocidas: «[...] Pues Aristóteles, príncipe de los filósofos, tiene por imposible que algún entendimiento criado pueda entender a Dios ni a las criaturas no usando de las figuras que en su fantasía imprime o ya tiene impresas [...] leed los doctores católicos en los lugares que de esto tratan y hallaréis afirmado y probado bastantemente que nuestro entendimiento cuanto tiempo estamos en el cuerpo y peregrinamos del Seńor no puede entender, ni por consiguiente amar a Dios, como tampoco a las criaturas, sin convertirse a las fantasías e imágenes que entonces se le ofrecen de nuevo, o a las que en su memoria tiene encerradas de las cosas que por algunos de los sentidos recibió o de cualquiera otra manera que su fantasía las pueda formar y representar al entendimiento y el entendimiento a la voluntad. Porque, como San Agustín dice, la voluntad nace de la inteligencia». Fray Juan de la Cruz (1962: 354-5).

11. Arbiol (1784: 371) refiere, como la fuente, el libro 2, cap. 12 de la Subida del Monte Carmelo. No es esa la formulación de San Juan de la Cruz, pero el capítulo referido sí versa sobre la necesidad de abandonar la imagen divina construida a semejanza de las cosas criadas, sobre todo en la fase de la contemplación: «Y por cuanto todas las cosas criadas [...] no pueden tener alguna proporción con el ser de Dios, de ahí se sigue que todo lo que imaginare a semejanza dellas no puede servir de medio próximo para la unión con El, antes, como decimos, mucho menos. [...] aunque a los principiantes son necesarias estas consideraciones y formas y modos de meditaciones [...], pero ha de ser de manera que pasen por ellos y no se estén siempre en ellos, porque de esa manera nunca llegarían al término, el cual no es como los medios remotos ni tiene que ver con ellos. [...] Por lo cual, el alma que hubiere de llegar en esta vida a la unión de aquel sumo descanso y bien por todos los grados de consideraciones, formas y noticias, ha de pasar y acabar con ellas, pues ninguna semejanza ni proporción tiene con el término a que se encaminan, que es Dios». San Juan de la Cruz: Subida del monte Carmelo (II, 12, 4-5) (1994: 324).

12. Arbiol (1784: 371). La guía espiritual de Arbiol (primera edición: 1706) se encuentra fuera del período al que se circunscribe el presente estudio. Sin embargo, he optado por incluirla, porque sistematiza de manera extraordinariamente clara la doctrina de la meditación. 
ce como la fase preparatoria a la contemplación, durante la cual la imagen sirve de instrumento de mediación que ayuda al devoto a acercarse a Dios, y su uso correcto, puntualiza San Juan de la Cruz, no debe confundirse con la doctrina de «aquellos pestíferos hombres que [...] quisieron quitar de delante de los ojos de los fieles el santo y necesario uso e lícita adoración de las imágenes de Dios y de los Santos». «Nuestra doctrina es muy diferente de aquélla [...]», dictamina: la imagen devota constituye el «medio para el fin [...] para acordarnos de Dios y de los Santos». ${ }^{13}$

En resumen, la imagen, en su vertiente material y también mental, está relacionada con las cuestiones centrales de la nueva pietas, a saber, con la polémica acerca de las manifestaciones externas de la piedad y acerca de la mediación en el proceso de la unión con lo divino. Cabe apuntar que los diferentes aspectos del debate en torno a la imagen se centran en su empleo correcto y controlado. En este contexto general se sitúa el presente estudio, que analizará la imagen que alimenta la oración y la meditación y cuyo empleo se dispone en los manuales devocionales de los siglos XVI y XVII. ${ }^{14}$

La literatura espiritual constituye el género más popular entre los libros que salieron de las prensas europeas en el siglo Xvi y en la primera mitad del siglo XVII, debido a la preocupación por los temas relacionados con la devoción y por las temáticas afines a la piedad, los ritos y las ceremonias religiosas, un interés especialmente patente después de la celebración del Concilio de Trento. A él se debe la proliferación extraordinaria de guías de espiritualidad, manuales de ejercicios piadosos, instrucciones doctrinales, espejos, artes e itineriarios del buen cristiano, que refieren desde las reglas de la espiritualidad más humilde hasta las exposiciones teologales más complejas.

Una gran parte de estos tratados propone ejercicios espirituales, cuya práctica posibilita la via spiritualis hacia la perfección cristiana. Introducen, por tanto, al devoto en métodos específicos del desarrollo espiritual, que permiten —a los más experimentados-, alcanzar la anhelada unión contemplativa con Dios, la experiencia directa de la presencia del Señor. Dentro de este corpus de guías espirituales cabe señalar los manuales de oración y meditación, que determinan los modos apropiados de la oración vocal y la mental, junto con las prácticas meditativas.

13. San Juan de la Cruz: Subida del monte Carmelo (II, 12, 4-5) (1994: 425).

14. Para una reciente aportación sobre las tesis teologales acerca del uso de la imagen, véase Dekoninck (2005), quien examina su estatus en la iconología jesuita del xvII; el primer capítulo de su estudio, "Les status de l'image: de la théologie symbolique à la tropologie rhétorique», sintetiza el pensamiento teologal anterior respecto al uso de la imagen en las prácticas devocionales. 
Una de las proposiciones surgidas del concilio de Trento, referente al uso de la imagen, «De invocatione, veneratione, et reliquiis sanctorum, et sacris imaginibus", postula que "[...] por medio de las historias de nuestra Redención, expresadas en pinturas, y otras copias» pueden los fieles contemplar «los saludables exemplos de los Santos, y los milagros que Dios ha obrado por ellos» para que «se exciten a adorar, y a amar a Dios, y practicar la piedad». ${ }^{15}$ Los tratados de meditación, entre los cuales figura el célebre Libro de oración y meditación de Luis de Granada (1566), y el de Pedro de Alcántara (Tratado de la oración y meditación, 1574, modelado, probablemente, sobre el texto de Granada) ${ }^{16}$ recurren al uso de la imagen precisamente para secundar estas pautas de la institución eclesiástica. Conforman instrumentos capitales de devoción, porque exponen los modos correctos de la meditación, una de las prácticas espirituales de mayor relevancia.

También los Ejercicios (1548 - primera edición latina, 1615 - primera edición castellana) de Ignacio de Loyola integran la meditación en un riguroso proyecto de prácticas devocionales, centrado en la reflexión interior y en el examen de la conciencia. Al lado de estos textos mayores hallamos incontables tratados menores; muchos de ellos, de carácter compilativo, sistematizan la doctrina de la oración o dilucidan sus premisas teóricas capitales; lo más importante es que todos ellos ofrecen al devoto la materia de la meditación, los temas más apropiados y provechosos. Suelen relatar sucesos de la vida de Jesús (especialmente la Pasión y el dolor de la Virgen), pero en ocasiones versan sobre otros temas, como la institución de la Sagrada Comunión, etc. Muchos textos se limitan a describir las escenas que deben ser consideradas, es decir, exponen narrativamente los diferentes pasos del vía crucis. Sirvan como ejemplo las Cinquenta meditaciones sobre toda la Passión de Christo Nuestro Señor (1601), compuestas por Francisco Costero para que, según se estipula en el prólogo, los fieles «reciban esfuerço, aliuio, y recreo diuino, y le traygan en los senos de sus coraçones como vn manogito de myrrha, que los preserue de corrupción». Para ello, pueden «leerlas, o oyrlas leer con reposo, sossiego, y ponderación»». ${ }^{17}$ En este tipo de manuales, el relato de la

15. "De invocatione, veneratione, et reliquiis sanctorum, et sacris imaginibus», en El sacrosanto y ecuménico Concilio de Trento (1785: 451).

16. Para una aportación reciente sobre la polémica influencia de ambos autores, véase San Pedro de Alcántara (2012: estudio introductorio).

17. Coster (1601: epístola dedicatoria). Especifica Coster que su manual sirve para «considerar cada día vn rato, según la possibilidad de cada vno, llana y senzillamente (como en estas meditaciones se enseña) la Passión del Señor; los exemplos que en ella nos da; las virtudes que nos enseña; los vicios que auemos de huyr, y cómo auemos de moderar nuestras passiones, y lleuar con paciencia los trabajos y agrauios; lo puede y deue hazer qualquier persona [...] le ayudará mucho el leerlas [...]. Y finalmente me parece que será como vn pequeño manual, que en ningún tiempo lo dexen de las manos, sino que cada día vsen del, como de vn ramillete de flores odoríferas [...], que son las virtudes de Christo [...], que los preserue de corrupción, para que no huelan mal a Dios; que tal es la Passión del Señor». Ibid. 
Pasión es extraordinariamente vívido, pero no contienen imágenes propiamente dichas. En cambio, un grupo menor de los manuales de oración propone la llamada bildmeditation, la meditación con imágenes, e incorpora, al lado del texto, grabados de los pasos de la Pasión. Estos textos son de extraordinario interés, no sólo para el análisis de las prácticas devocionales y la oración personal, sino también desde el punto de vista de la fenomenología de la imagen, porque, en palabras de Pierre Civil, invierten la habitual función parafrástica de la imagen que explica o glosa el texto para complementar su significado, convirtiéndola en un elemento que, al contrario, "genera el discurso que la acompaña». ${ }^{18}$

Las meditaciones iconográficas exhiben, de esta forma, la imagen (figura), complementada por una exposición que guía y determina el curso de la meditación. Algunos textos incorporan elementos adicionales (como pueden ser los pasajes bíblicos correspondientes al paso presentado, avisos, comentarios o digresiones doctrinales).

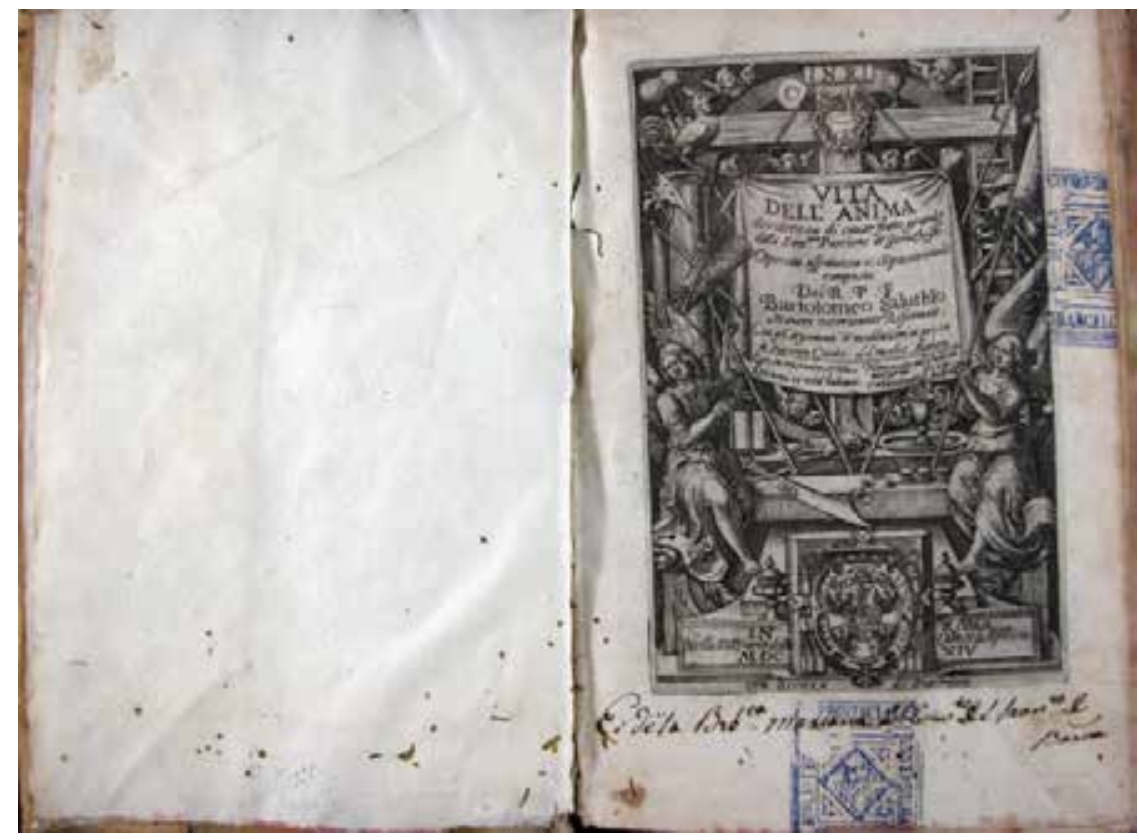

Figura 1.

Bartolomeo Cambi: Vita dell'anima desiderosa di cauar frutto grande dalla Santme. Passione di Giesu Christo, 1614, la portada.

18. Cf. Civil (1995: 25). 




Figura 2.

Bartolomeo Cambi: Vita dell'anima desiderosa di cauar frutto grande dalla Santme. Passione di Giesu Christo, 1614. Canto qvarto. La imagen (Jesús conducido a casa de Anna) viene acompańada por varios elementos textuales (el «argomento», los marginalia, el poema).

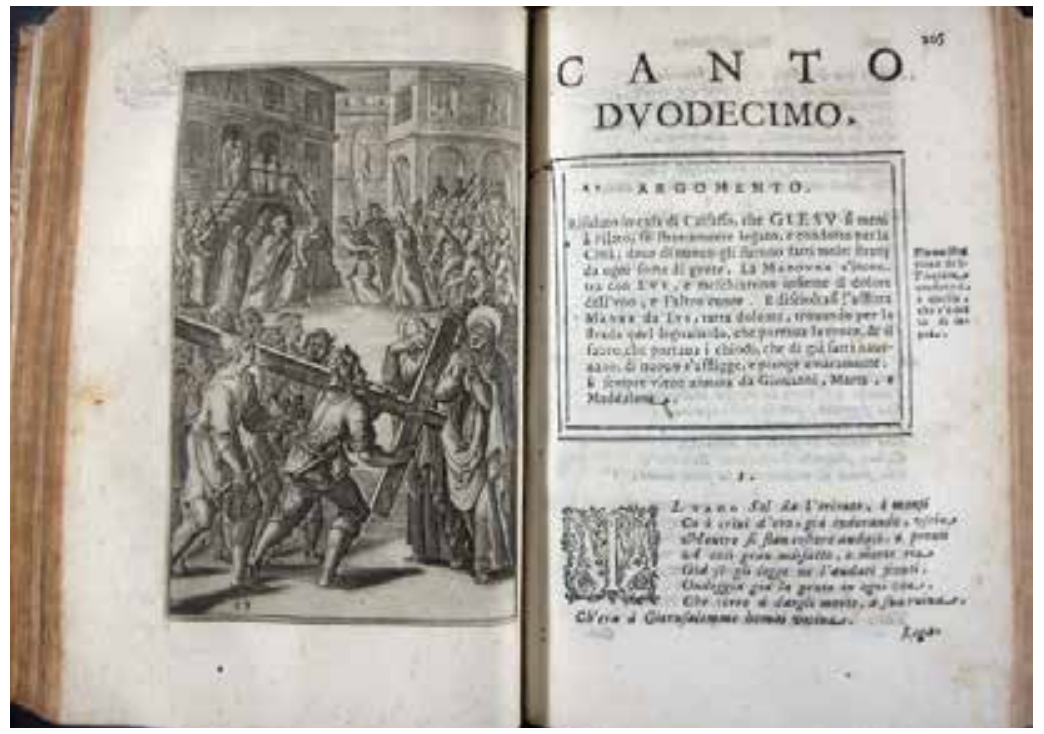

Figura 3.

Bartolomeo Cambi: Vita dell'anima desiderosa di cauar frutto grande dalla Santme. Passione di Giesu Christo, 1614. Canto XII: Jesús conducido por la calle. 


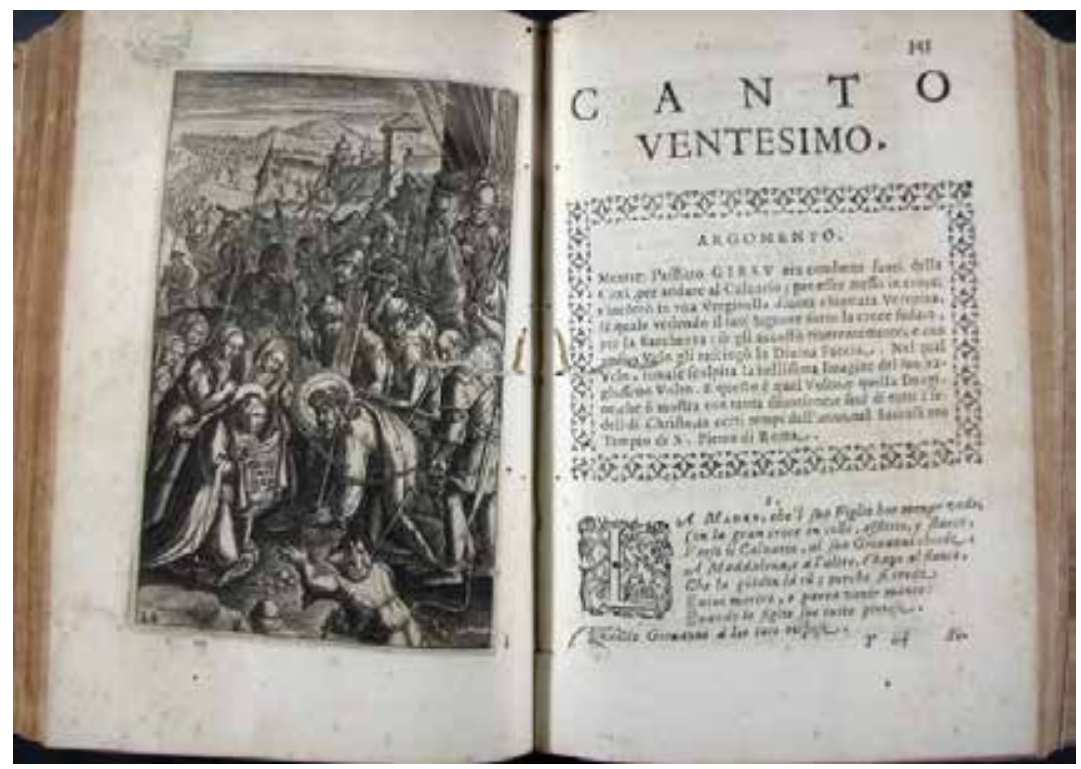

Figura 4.

Bartolomeo Cambi: Vita dell'anima desiderosa di cauar frutto grande dalla Santme. Passione di Giesu Christo, 1614. Canto XX: Jesús en el Calvario.

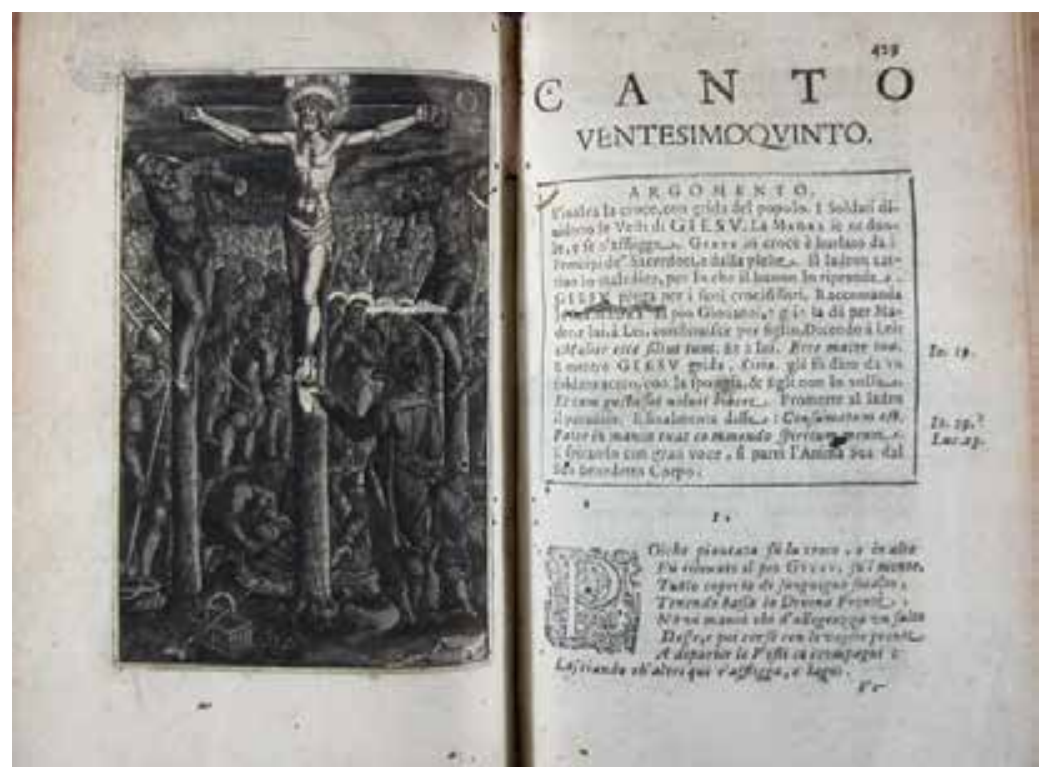

Figura 5.

Bartolomeo Cambi: Vita dell'anima desiderosa di cauar frutto grande dalla Santme. Passione di Giesu Christo, 1614. Canto XXV: Crucifixión. 


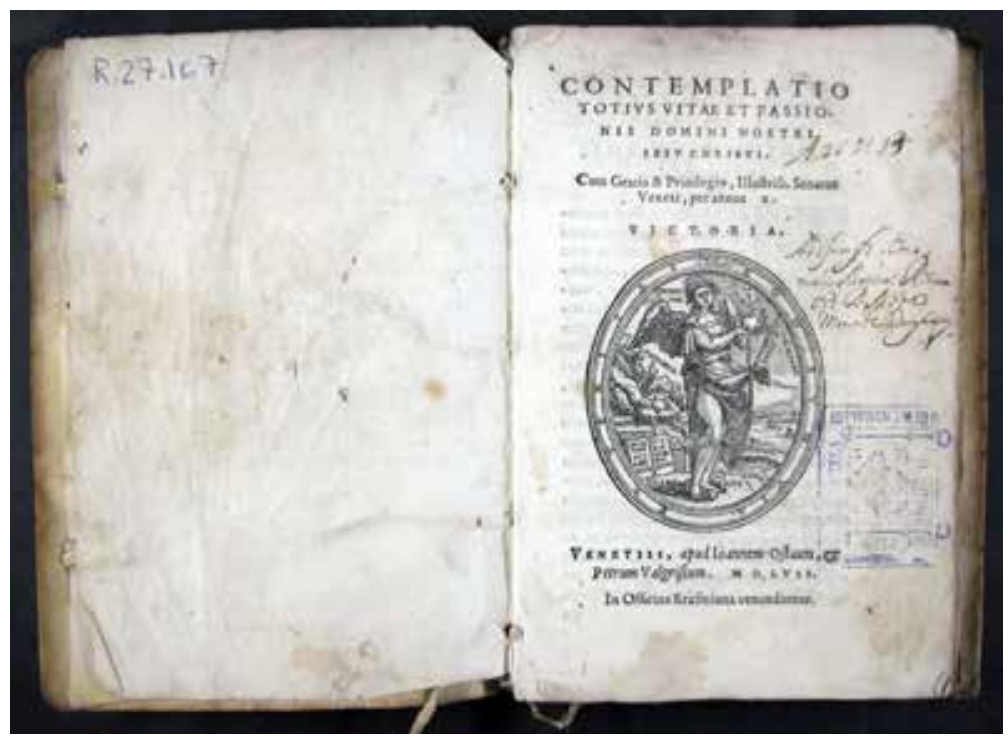

Figura 6.

Un ejemplo de los tratados de meditación latinos: Contemplatio totivs vitae et passionis Domini Nostri Iesv Christi, Venecia, 1557.

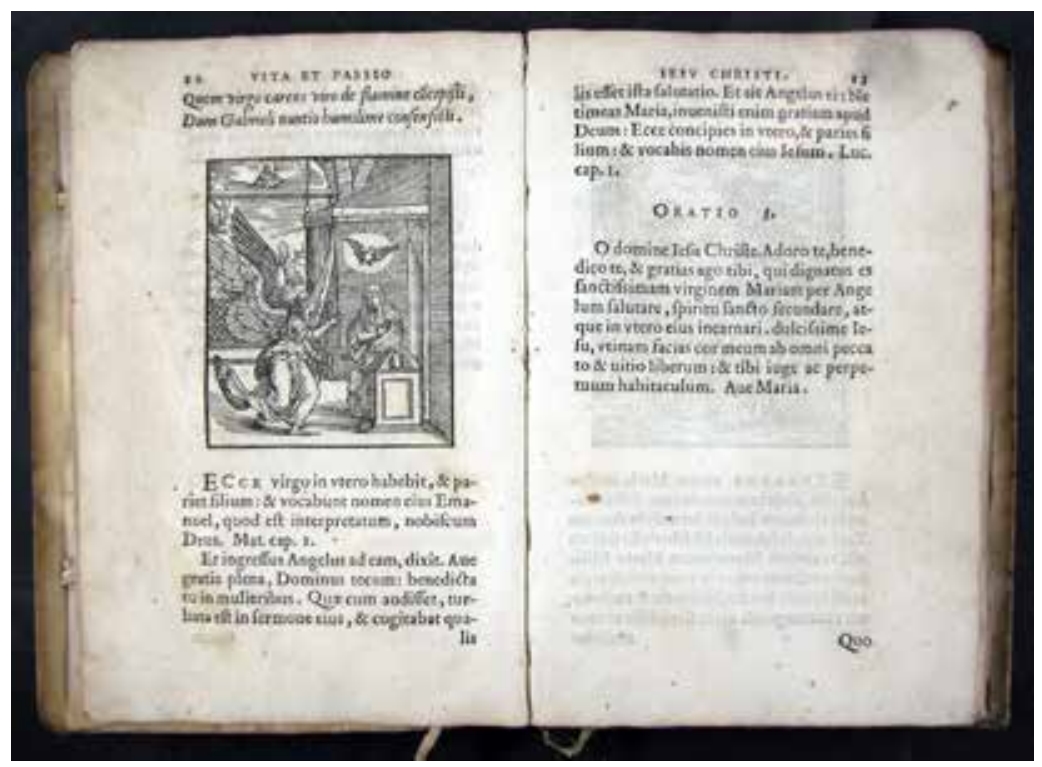

Figura 7.

Contemplatio totivs vitae et passionis Domini Nostri Iesv Christi: cum gratia \& priuilegio illustriss. senatus veneti per annos $X, 1557$. La anunciación. La parte textual incluye una breve adnotatio y una oración. 

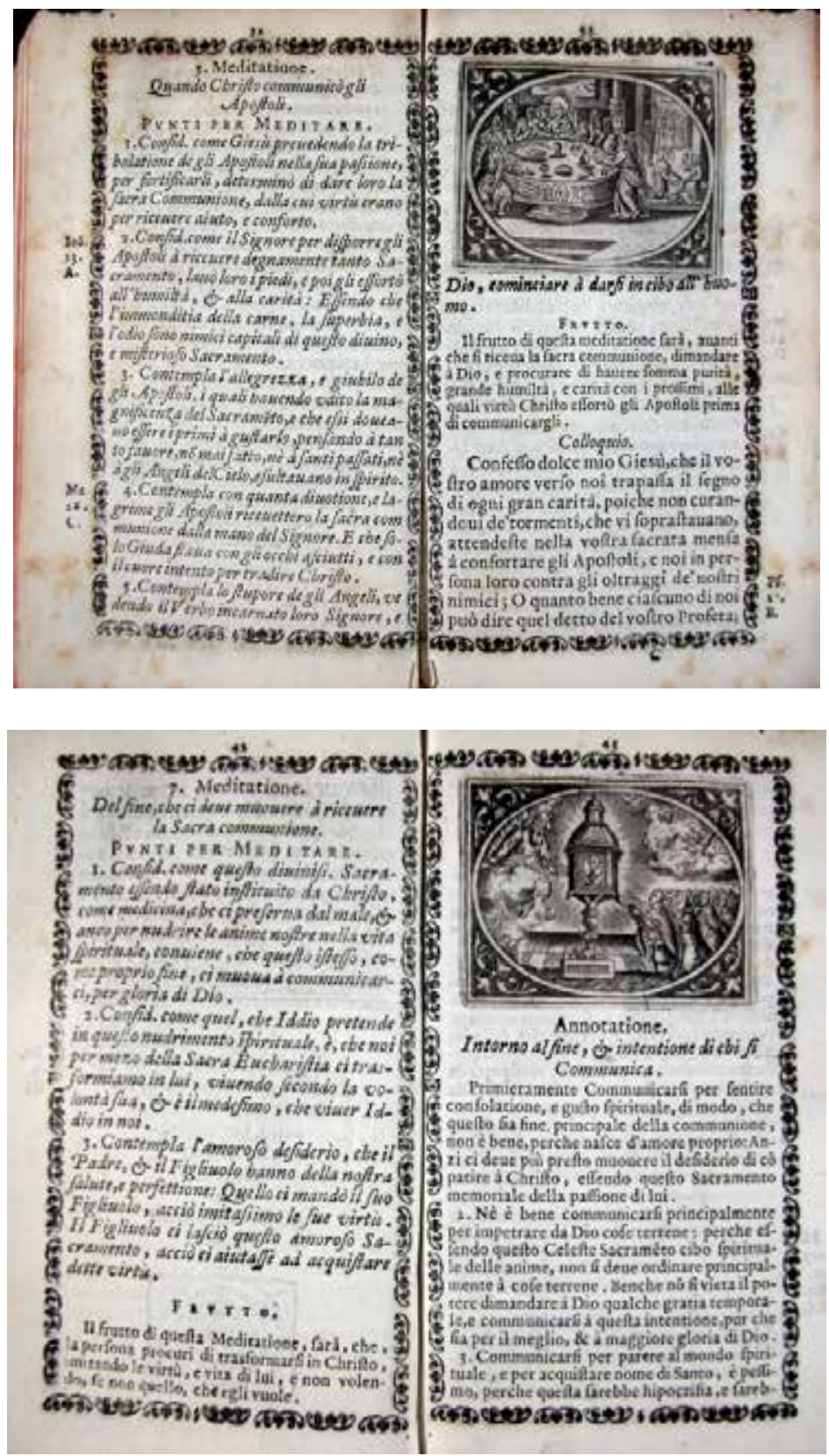

Figuras 8 y 9 .

Ejemplo de un tratado de meditación con la parte textual especialmente copiosa, que incluye, para cada escena, los "punti per meditare», el "frutto», «annotatione» (exposición de los puntos doctrinales) y el "coloquio». Luca Pinelli: Libretto di brevi meditationi del Santiss. Sacramento e della preparatione alla sacra communione, 1598. 

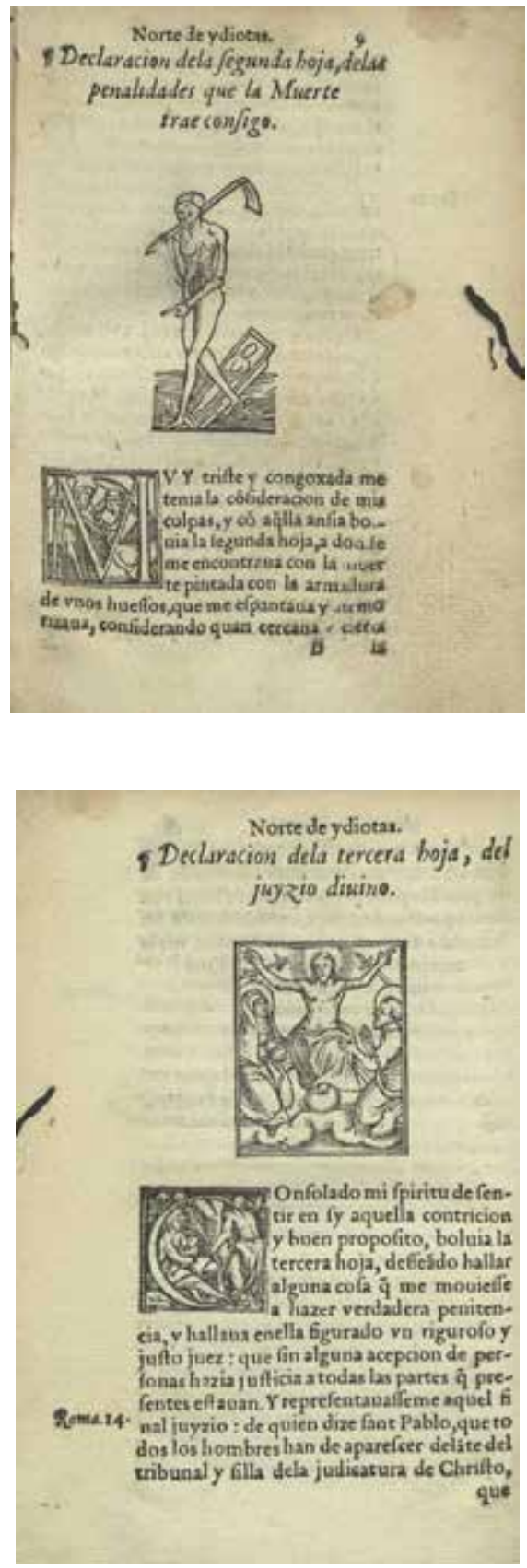

\section{Figuras 10 y 11.}

Francisco de Monzón: Norte de ydiotas compuesto y reuisto por el doctor Francisco de Móçon, a donde se trata vn exercicio muy spiritual y prouechoso, 1563. Declaración de la segunda y de la tercera hoja. 
La meditación se inspira y fundamenta en la imagen, pero la función de la figura es, desde el punto de vista teológico e iconográfico, más compleja aún, si cabe. Paradójicamente, es la vista, uno de los cinco sentidos, el que permite abandonar y trascender el mundo sensible. La imagen propicia la translatio ad prototypum, esto es, permite acceder a lo divino, al prototipo inmaterial al que representa. ${ }^{19}$ Se inscribe, en este sentido, en la doctrina eclesiástica referente a la imagen sacra y su veneración, según la cual la imagen (el ídolo) es una mera representación que bajo ninguna circunstancia encarna directamente al objeto o la sustancia original. ${ }^{20} \mathrm{La}$ imagen, por tanto, ejerce de elemento de mediación en la vivencia espiritual, pero en sí constituye un componente estrictamente auxiliar. Antonio Arbiol afirma rotundamente que en «la veneración de las Santas Imágenes» el devoto no debe "detenerse en lo sensible del Retrato», sino pasar "con su veneración al original». "Las veneramos», explica, "porque nos representan a los Santos que están en el Cielo, y despiertan nuestros afectos a verdadera devoción, conforme está definido en el Santo Concilio Tridentino. Por lo qual no se ha de embarazar el afecto en lo material de la Imagen, sino elevarle luego a su original, que está en la Gloria», ${ }^{21}$ subiendo "como un relámpago, de las Imágenes que están en la tierra, a los originales que están en el Cielo» (y no olvida explicitar que así "lo enseña el santo Concilio Tridentino»). ${ }^{22}$

Ahora bien, para poder contextualizar adecuadamente la práctica de la meditación, debemos tener en cuenta que la mayoría de las guías y manuales prácticos de espiritualidad aspiran a desbrozar la vía de la perfección espiritual que culmina en la unión. Por consiguiente, el tema de la vivencia del amor de Dios y la experiencia de la comunicación divina no puede circunscribirse únicamente a las corrientes místicas: es el hilo conductor de todas las guías de espiritualidad.

19. Civil (1995: 135).

20. Según las tesis oficiales del Concilio de Trento, «[a las imágenes de Cristo, de la Virgen madre de Dios, y de otros Santos] se les debe dar el correspondiente honor y veneración: no porque se crea que hay en ellas divinidad, o virtud alguna por la que merezcan el culto: o que se les deba pedir alguna cosa; o que se haya de poner la confianza en las imágenes, como hacían en otros tiempo los gentiles [...] sino porque el honor que se da a las imágenes, se refiere a los originales representados en ellas: de suerte, que adoremos a Cristo por medio de las imágenes que besamos, y en cuya presencia nos destocamos; y veneremos a los Santos, cuya semejanza tienen: todo lo qual es lo que se halla establecido en los decretos de los concilios, y en especial en los del segundo Niceno, contra los impugnadores de las imágenes». «De invocatione, veneratione, et reliquiis Sanctorum, et sacris imaginibus» (1785: 450). La cursiva es mía. Muchos tratados se hacen eco de esta tesis doctrinal. Diego de la Madre de Dios (1713: 351) puntualiza que «se deben adorar las Imágenes Sagradas de Christo Señor nuestro, de su Madre Santíssima, y de los Santos. Débeseles la misma adoración, que a sus Prototypos, o exemplares, salvo que a estos es absoluta, y a las Imágenes respectiva. Hanse de adorar no solo con culto externo [...] sino también con interno culto, y afecto de interior sumissión, el qual no ha de parar en la Imagen sino que ha de mirar, y passar a adorar el exemplar, por el qual se adora su Imagen [...]. No es necessario que aya dos actos; vno para adorar la Imagen; y otro para el exemplar, sino que basta vno».

21. Arbiol (1784: 469).

22. Arbiol (1784: 277).

Studia Aurea, 9, 2015 
En este sentido, la doctrina cristiana ha postulado tres vías para el perfeccionamiento espiritual: la vía purgativa, centrada en el examen de la conciencia y la purificación ${ }^{23}$ la vía iluminativa, que conoce a Dios y sus beneficios a través del entendimiento, en la que el «alma se va iluminando con la frequente consideración de los beneficios divinos, [...] muere al mundo y nace para Dios»; ${ }^{24}$ y la vía unitiva, por medio de la cual el alma purificada alcanza el momento de la unión, un acto compuesto de "Fe viva, y Caridad encendida». ${ }^{25}$ Antonio Arbiol explica que la meditación se hace por discurso, ${ }^{26}$ pero la contemplación es un «sencillo conocimiento de la verdad, sin discurso, aunque precedió el discurrir para hallar la verdad». ${ }^{27}$ Es una vía que aspira a consumar la unión mística del alma con Dios, a la que Tomás de Villacastín describe como «unir, y juntar nuestro espíritu con Dios, y con unión de perfecto amor, holgándose de sus inmensas, e infinitas riquezas, y perfecciones, alegrándose de su infinita gloria, poder, y saber, deseando que sea conocido por todo el mundo, y que se cumpla siempre su santa, y divina voluntad en todas sus criaturas, pues este es el camino por donde caminan los que llegan al estado de perfectos, y consumados en la virtud». ${ }^{28} \mathrm{~A}$ veces, la meditación se circunscribe solamente a una de las tres vías (generalmente la purgativa). En general, no obstante, los tratados espirituales parecen sugerir que las tres vías forman parte de la doctrina y perfeccionamiento espiritual (ordenada en una secuencia progresiva e iniciática que va desde la purgación hasta la contemplación), y que las tres son accesibles a los devotos. Algunos autores, además, establecen diferentes meditaciones para diferentes vías. ${ }^{29}$

En relación con las prácticas meditativas, el orden de las tres vías debe completarse con otra secuencia, paralela, de la scala. Al igual que las tres vías, la scala representa un ascenso gradual hacia la unión contemplativa, pero mientras

23. Según Antonio de Molina (1635: s.f.), tres son los componentes de la vía ascética: «1. aspereza y mal tratamiento de la carne, en la vileza y aspereza y templança del comer y beuer, en el vestir, y en la cama, y en todas las cosas que vsare: en el estar de rodillas, o en pie, o en Cruz, o postrado en la oración: en tomar disciplinas, entrar cilicio, en ayunos, y sobre todo, en las vigilias santas en oración; 2. mortificación interior de sí mismo, y de sus apetitos, y sensuales inclinaciones, y en la abnegación de su propia voluntad, por cumplir la diuina; 3 . ser solicito en la continua oración [...] andar siempre en la presencia del Seńor [...] si quiere ser purissimo y perfectissimo holocausto suyo; con los ayunos y asperezas corporales, se santifica la carne; con la mortificación y abnegación de todos los apetitos, se purifica el ánima, y con la oración y contemplación, se perficiona el espíritu; el qual allegándose a Dios, se haze vna cosa con él, que es su vltima perfección». 24. Arbiol (1784: 586). La vía purgativa, continúa Arbiol, «arranca las malas raíces, purga los pecados $[. .$.$] quita los vicios»; la iluminativa «siembra y transplanta hierbas y flores de virtudes,$ ilumina el entendimiento, y comienza a mover en la voluntad afectos de amor de Dios». Ibid.

25. Arbiol (1784: 568).

26. Arbiol (1784: 568).

27. Arbiol (1784: 568).

28. Tomás de Villacastín (1714: 62).

29. Cf. Tomás de Villacastín (1714: 61), quien describe una serie meditaciones y puntos «que pertenecen a la via purgativa». 
que la doctrina de las tres vías encarna un modelo teórico del acceso a Dios, la scala se concibe más bien como una exposición práctica de este camino. Prescribe un conjunto de ejercicios espirituales (lectura, meditación, oración, contemplación) ${ }^{30}$ y asienta, en consecuencia, la meditación firmemente en una serie de prácticas espirituales. Baste citar a Luis de Puente, quien subraya que sus Meditaciones están dirigidas a los que «dessean subir cada día por la escalera mystica de Iacob, que san Agustín llama escalera del Parayso, y san Bernardo, escalera de religiosos: cuyos escalones son lección, meditación, oración y contemplación». Todos ellos hallarán en su libro «materia y enseñanza para esta subida», para «llegar a la vnión con el Señor, que está en su cumbre, conbidándonos a subir por ella». ${ }^{31}$ La scala se articula como un ascenso, como un proceso paulatino y progresivo; la lectura busca, la oración demanda, y la contemplación gusta, según la sistematización más conspicua de esta secuencia, la Scala claustralium del cartujano Guigo II. ${ }^{32}$ La meditación, a su vez, es una consideración que encuentra («Beatae vitae dulcedinem lectio inquirit, meditatio invenit, oratio postulat, contemplatio degustat»), ${ }^{33}$ es una forma de recogimiento y una manera de "tratar con Dios», ${ }^{34}$ un "atento y cuidadoso pensar, o considerar el paso que se ha prevenido para la oración, con todas sus circunstancias y accidentes, que conducen para mover en la voluntad espiritual afectos, para aborrecer las culpas, y amar a Dios nuestro Señor», según Antonio Arbiol (1784: 555). Su materia son «los misterios de nuestra Santa Fe Católica, y extensivamente todas las criaturas del Cielo y de la tierra». ${ }^{35}$

El uso de la imagen —en cuanto figura material pero también mental— en el desarrollo espiritual se relaciona, asimismo, con una cuestión teológica de

30. Algunos autores de los tratados de meditación (entre ellos Luis de Granada) añaden otras fases a esta secuencia, como, por ejemplo, el hacimiento de gracias, la petición, el ofrecimiento. Arbiol (1784: 552) aclara que, según algunos, son cinco las partes de la oración mental (preparación, lección, meditación o contemplación, hacimiento de gracias, y petición), mientras que otros mencionan siete (preparación, lección, meditación/contemplación, hacimiento de gracias, ofrecimiento del corazón, petición).

31. Luis de Puente (1609: 47).

32. Guigo II, Scala claustralium (2001), p. 84. Guigo II fue el prior del monasterio de la Gran Cartuja a partir del año 1173 y autor de 12 Meditationes y posiblemente también de la meditación sobre el Magnificat (Tractatus super canticum de evangelio scilicet Magnificat). Su Scala, extraordinariamente popular, solía atribuirse en la Edad Media a San Agustín o a San Bernardo.

33. Guigo II, Scala claustralium (2001), p. 84. Cf. Andreu Capella (1616: s.f.) quien explica en el primer capítulo, titulado "Che cosa sia Oratione. E si diuide in Meditatione, e Contemplatione», que la meditación se llama «la consideratione, laqual si fa col discorso dell'intelletto, pero cui mezzo si cerca, e troua alcuna cosa, como per essempio, quando per venir alla cognitione della grauezza de' peccati nostri, andiamo considerando, che siamo noi peccatori, \& chi è Dio, contra del quale habbiamo peccato, parimente, quando per acquistar qualche conoscimento delle Diuine perfettioni, quelle delle cose create vogliamo per la mente, onde racogliendo andiamo, quali debban esser quelle di colui, che le ha create». La cursiva es mía.

34. Fray Luis de Granada (1994: 270).

35. Arbiol (1784: 555).

Studia Aurea, 9, 2015 
primer orden, la de la posibilidad y las fórmulas correctas del conocimiento de Dios. El cristianismo postula dos vías complementarias para llegar al entendimiento del Señor. Por una parte, el modo catafático (la vía afirmativa), que "consiste en expresar el conocimiento de Dios a través de imágenes, símbolos o conceptos». ${ }^{36}$ Por la otra, el modo apofático (la vía negativa), que recurre a la negación sistemática de toda referencia a Dios que no sea la experiencia misma de la unión mística cuando, según el testimonio de Pseudo Dionisio, recogido en muchos manuales de meditación, "el alma se despoja de todo cuanto ve y entiende, [y penetra], en las misteriosas tinieblas del no-saber». ${ }^{37}$

Los dos procedimientos son necesariamente complementarios, ya que el método catafático encarna, en realidad, sólo la primera fase del entendimiento, que conoce al Señor "por figuras sensibles», a través de la perfección de las cosas criadas. Como explica Pedro de Villalobos, es imposible aprehender a Dios tal "como está en sí, si no es por medio de las criaturas»: estas son medios, y escala para conocerle. ${ }^{38} \mathrm{La}$ comprensión por «especies materiales» es indispensable para conocer «aquella inmaterial substancia». ${ }^{39}$ De ahí la sinergia de las dos vías de conocimiento, de la que puede inferirse también la causa última de la scala spiritualis: el entendimiento material tiene que iniciarse por las especies corpóreas para poder penetrar, a continuación, en las espirituales.

El modelo de la scala - y del ascenso en general - se fundamenta, en resumen, en una secuencia epistémica y teológica que vincula la práctica espiritual a las fórmulas de aprehensión de la esencia suprema. La meditación forma una parte ineludible de ella, porque proporciona aquellas imágenes y figuras sensibles (las criaturas, a saber, las cosas registradas por los sentidos exteriores) que pemiten al espíritu elevarse hacia las especies inmateriales. Los visibilia instituyen el medio hacia los invisibilia, que sólo después podrán ser asidos a través del entendimiento contemplativo..$^{40} \mathrm{El}$ ascenso espiritual avanza, obligatoriamente, desde lo sensible hacia lo intelectual e inmaterial. ${ }^{41}$

36. Mujica Pinilla (2005: 180).

37. Mujica Pinilla (2005: 180).

38. Pedro de Villalobos (1675: 133).

39. Pedro de Villalobos (1675: 63).

40. Cf. Freedberg (2009), esp. el capítulo 8: «Invisibilia per visibilia: la meditación y los usos de la teoría».

41. Explica Pedro de Villalobos (1675: 83-91), siguiendo a Santo Tomás, que el acto de Fe (la contemplación de $\mathrm{Fe}$ ) es posible por razón natural o por revelación. Ésta última requiere «un entendimiento apartado de las imágenes sensibles y acostumbrado a entender, no por luz imaginaria, y razón natural, sino [..] por luz superior». Está, por ello, reservada solamente a pocos, y es una concesión extraordinaria de Dios, porque «el entendimiento [sobre todo el de los nueuos contemplatiuos] no puede desasirse de las imágenes sensibles y de la luz de la razón». De ahí que sea preciso dirigirse hacia la contemplación por razón natural (y hacia la meditación imaginaria), esto es, "pasar primero por los grados imperfectos para llegar a los perfectos», conociendo a Dios «indirectamente $[\ldots]$ por las criaturas $[\ldots]$ por las cosas que registraron sus sentidos exteriores». 
Estas consideraciones sostienen la premisas teóricas sobre la presencia de la imagen material durante la meditación. Según Luis de Puente, ayuda mucho, durante el ejercicio, «hazer dentro de nosotros alguna figura o imagen de la cosa que pretendemos meditar, con la mayor viueza y propriedad que pudiéremos». La imagen pone «delante del alma espiritualmente la cosa que medita, como si la tuuiera presente». Si tengo que pensar en el infierno, advierte Luis de Puente, «imaginaré vn lugar como un calaboço oscuro, estrecho, y horrible, lleno de fuego, y las almas dentro dél, ardiendo en medio de aquellas llamas. Y si he de pensar en el Nacimiento, formaré vna figura de vn portal desabrigado, y a vn niño embuelto en pañales, puesto en vn pesebre». ${ }^{42}$ La figura material, en definitiva, sostiene o ayuda a conformar la imagen mental; en este sentido, las colecciones de meditaciones proporcionan al creyente un repertorio de temas; sirven como disposiciones de la inventio, ofreciéndole el argumento y el contenido de la meditación. «La materia de que se ha de tener la oración», afirma Diego de la Madre de Dios en su Arte mistica, se halla «leyendo los libros sagrados, o los libros devotos, que de los sagrados se han sacado. Para la Oración será mejor leer los que tratan de las meditaciones, o puntos sobre que se ha de orar, porque más prompta, y fácilmente ofrecen la materia dispuesta». 43

Desde este punto de vista, la imagen, en la secuencia de ejercicios, no sólo dispone el espíritu como una suerte de captatio benevolentiae iconográfica, sino que aporta la base y la justificación misma de la scala spiritualis. Su función es propedéutica y parafrástica, indudablemente — porque complementa el texto de la meditación-, pero, al mismo tiempo, media entre lo visible y lo invisible, entre el mundo material y la presencia interior». ${ }^{44} \mathrm{Al}$ interiorizar la figura, el fiel, en la conjunción de la comprensión intelectual y la emoción suscitada, interioriza el misterio. La imagen, comenta F. Lecercle (1990: 49), le permite abstraerse de lo tangible y penetrar, con los ojos, en el mundo del espíritu.

Según el testimonio de Pedro de Villalobos, la meditación imaginaria «lleva al conocimiento de la divinidad, y también a su amor». A continuación añade que la práctica se orienta a "reformar las costumbres antiguas, y vestirles de virtudes», y por ello es pertinente «tener un dechado, y exemplar, de donde

42. Luis de Puente (1609: 25), apartado VII, titulado «Del modo cómo nos hemos de ayudar de la imaginación y lengua, y las demás potencias para la oración mental». El autor explica a continuación que la oración mental es obra de las tres potencias supremas del alma, pero ayudan para ejercitarla las potencias inferiores, «entre las quales la primera es, la imaginatiua: la qual assí como impide notablemente la oración quando está mal domada y es vagabunda: assí también ayuda mucho quando puede con facilidad formar dentro de sí algunas figuras, o imágenes de las cosas que se han de meditar: porque esto es como atarla a vn solo lugar [...]». Luis de Puente (1609: 24). Advierte, a continuación (1609: 25) que «los muy imaginatiuos han de estar sobre auiso, porque sus vehementes imaginaciones les pueden ser ocasión de muchas ilusiones, pensando que su imaginación es revelación, y que la imagen que dentro de sí forman, es la misma cosa que imaginan». 43. Diego de la Madre de Dios (1713: 13).

44. Cf. Civil (1995: 124). 
vayan sacando, e imitando aquellas mismas virtudes». ${ }^{45}$ Pero, ¿cómo se articula exactamente esta interiorización de las excelencias del ejemplo proporcionado? La meditación se define, stricto sensu, como un ejercicio íntimo, un retiro solitario en presencia divina, una comunión con el Señor no condicionada por lo tangible y por lo material. Sin embargo, en los manuales de devoción convergen, paradójicamente, la piedad individual con las actitudes y convicciones espirituales colectivas, determinadas por el dogma y por la institución eclesiástica. Los actos de piedad expuestos en ellos están supeditados, ineludiblemente, al régimen doctrinal, porque siguen itinerarios muy precisos que dirigen, desde las posiciones del dogma, la vivencia íntima de la búsqueda de Dios.

En ello radica una de las paradojas más notables de las guías de oración y meditación, extrapolable a todos los manuales de espiritualidad en conjunto, a saber: exponen la devoción como un acto íntimo y personal, pero, simultáneamente, pretenden gobernarlo y pautarlo: «Para conocer a Dios», sostiene Pedro de Villalobos, usamos «de algunas guías, o nortes, que lleuan como de la mano a nuestro entendimiento». ${ }^{46}$ Cabe preguntarse, por tanto, cómo interviene el hombre -o mejor dicho, la institución y la doctrina - en una vivencia tan personal que es la comunión con el Señor, y qué papel desempeña la imagen en la proscripción y la censura de aquellas experiencias y actitudes devocionales que son inadmisibles para el dogma.

La conceptualización tradicional de la censura la interpreta como un instrumento coercitivo y represivo, un medio para eliminar el disenso y un agente del control social. Sin embargo, el estudio de la actuación censoria, centrado en la manipulación directa y material del texto (o de la imagen), debe complementarse con análisis de modos menos explícitos de la intervención en la conciencia. Al lado de los regímenes sancionadores de crimen y castigo, prohibición y herejía, asociados con la visión convencional de la censura, estas formas difusas no se ejercen, según María José Vega (2012: 12), «de forma coercitiva [...] sino a través de la persuasión, la propaganda y el discurso pedagógico y moralista, esto es, mediante instrumentos de consenso social, de creación de convicciones y de regulación de la conducta». En ello, la idea de la censura difusa es afín al disciplinamiento social —una noción que devino en objeto, en los últimos decenios, de un intenso debate en ámbitos historiográficos y sociológicos. Con todo, también la idea del disciplinamiento social, del mismo modo que la visión tradicional de la censura, incide, probablemente bajo la influencia del discurso foucaultiano, ante todo en los aspectos represivos y punitivos. ${ }^{47}$

45. Pedro de Villalobos (1675: 150).

46. Pedro de Villalobos (1675: 150).

47. Me gustaría citar, por extenso, la siguiente formulación de Federico Palomo (2007: 242), porque resume, de manera ejemplar, la asociación tradicional de la noción del disciplinamiento social con las formas explícitas de la censura: «Conviene llamar la atención, sin embargo, sobre una particular tendencia que se aprecia en el uso que los historiadores peninsulares han venido 
En mi opinión, la noción del disciplinamiento es idónea para discernir también aquellas formas de control inherentes al discurso doctrinal (reformista o contrarreformista), que no son explícitamente prohibitivas y punitivas. Es apropiada para asir teóricamente las formas sutiles e implícitas de dominación, instrumentos y recursos persuasivos - discursivos o iconográficos- centrados en la difusión y afianzamiento de un orden moral, religioso y social. De atender a Federico Palomo, estas formas tácitas e indirectas fueron más eficaces para el control de las conductas de los fieles que «las actividades desplegadas por las varias instancias de la justicia eclesiástica», esto es, los instrumentos stricto sensu punitivos o represivos. «Libros de devoción, imágenes, sermones, piezas de teatro, procesiones, sacramentos», considera Palomo (2007: 242), «sirvieron de marco y de contexto para elaborar, articular y difundir —impregnando al conjunto de los sujetos- un discurso religioso [que no se limitaba a fijar un puñado de preceptos doctrinales]».

De ahí que la noción del disciplinamiento sea apropiada para la exploración de los directorios altomodernos de la vida espiritual —entre ellos las guías de meditación - como textos que desvelan las destrezas de la ortodoxia en la prevención de las desviaciones y excesos doctrinales. Como hemos visto, las prácticas devocionales devienen en objeto de un profundo debate doctrinal explícito, sobre todo en lo referente a la oración vocal y mental. A pesar de ello, los manuales de oración y meditación trazan la vía oficial de la perfección también de manera más velada — a través de la simbiosis entre los elementos iconográficos y los discursivos-, no mediante postulados explícitos, sino encauzando el pensamiento y la percepción, y exponiendo determinados modelos de comportamiento y formas de vivir la espiritualidad y el encuentro con lo sagrado. ${ }^{48}$

«Muchos provechos se siguen generalmente de la vista y adoración de las imágenes, y principalmente a las personas simples y sin letras que, según se dice, son sus libros adonde leen y aprenden», advierte Francisco de Monzón en su Norte de Ydiotas, añadiendo que «este género de lección en las imágenes es tan

haciendo de ambos términos y, en especial, del concepto de disciplinamiento social. Como consecuencia, tal vez, de una visión más "foucaultiana», éste suele asociarse principalmente (o apenas) a esa dimensión coercitiva que, como se sabe, caracterizó muchas de las formas de intervención desarrolladas por las autoridades religiosas y eclesiásticas en la España y el Portugal de la época moderna. Ciertamente, ese perfil represor o punitivo es intrínseco a la propia noción de disciplina, haciéndose explícito, dentro del campo religioso moderno, en muchas de las actuaciones de los tribunales eclesiásticos (inquisitoriales y episcopales) o en diferentes dispositivos de control, como las visitas pastorales, los libros parroquiales, las listas de confesados o, incluso, el sacramento de la penitencia».

48. Cf. Palomo (1997: 127). Palomo destaca especialmente el discurso pedagógico como un vehículo privilegiado del disciplinamiento social. Añadamos que el riquísimo corpus de tratados espirituales altomodernos (guías, nortes, manuales, directorios, artes etc.), frecuentemente dirigidos explícitamente a lectores iletrados, constituye otro instrumento excepcional de este disciplinamiento de las conciencias. 
conveniente como la de los libros». ${ }^{49}$ De su afirmación podemos deducir que a la imagen se le puede atribuir la misma capacidad para sostener los modos de disciplinamiento que al texto, que también la figura puede dirigir la vivencia de la piedad. «Mediante la figuración visual», resume Federico Palomo (2007: 261), refiriéndose precisamente a los manuales espirituales, «se ponía una vez más de manifiesto esa voluntad por formular y articular el discurso religioso contrarreformista, tanto en su dimensión doctrinal como devota, en función de los horizontes de recepción [...]».

El papel de la imagen en este disciplinamiento de las conductas debe relacionarse, en primer lugar, con la cuestión de los límites y de la libertad de la imaginación. Muchos tratadistas manifiestan la conveniencia - y la necesidad- de recoger la imaginación, "para que no ande libre, discurriendo por do quisiere; sino que esté siempre atada a santas consideraciones y pensamientos», ${ }^{50}$ según proclama Antonio de Molina en sus Exercicios espirituales mvy provechosos para personas ocupadas, desseosas de su saluación (1635). Al ofrecerle al devoto la materia santa para escudriñarla y meditar sobre ella, las guías, en realidad, restringen la potencia imaginativa, ya que es preciso, en palabras de Luis de Puente, «ata[rla] [...] a un solo lugar», ${ }^{51}$ para que no se derrame y no ande vagando. $\mathrm{Na}$ turalmente, estos testimonios refieren, in primis, el imperativo de una concentración profunda que evita distracciones durante el ejercicio piadoso. Con todo, de acuerdo con el decreto tridentino sobre el uso de las imágenes, allí donde postula, recordemos, que "por medio de las historias de nuestra Redención, expresadas en pinturas, y otras copias, se instruye y confirma el pueblo recordándoles los artículos de la Fe y recapacitándoles continuamente en ellos", ${ }^{52}$ los directorios ambicionan no sólo contener la imaginación, sino también enderezarla, encauzar su rumbo para poder explotarla de manera apropiada. Lo corrobora, sin ambajes, Pedro de Villalobos, en una de sus reglas de la correcta meditación imaginaria, en la que prescribe que el devoto debe atenerse, en la formación de las imágenes,

49. Francisco de Monzón, Norte de Ydiotas (1563) en Civil (1995: 145).

50. Antonio de Molina (1635: s. f.). Todo el pasaje enfatiza la necesidad de refrenar y limitar la imaginación: «Mas aquí es de notar, que para la perfección deste holocausto, aun faltan dos cosas: porque en el cuerpo ay sentidos, y en el alma imaginación, y pensamientos: por donde a estas tres cosas deuemos añadir otras dos, que son la guarda de los ojos y sentidos: conuiene saber, de los oydos, y mucho más de la lengua; que es la llaue de todo, y la guarda del coraçón, o de la imaginación, para que no ande libre, discurriendo por do quisiere; sino que esté siempre atadas a santas consideraciones y pensamientos. Porque como dize S. Bernardo, no basta al varón deuoto, que tenga enfrenados sus afectos, si no tiene también enfrenada y recogida su imaginación».

51. Luis de Puente (1609: 32).

52. "De invocatione, veneratione, et reliquiis sanctorum, et sacris imaginibus», en El sacrosanto y ecuménico Concilio de Trento (1785: 451), la cursiva es mía. El texto prosigue de la siguiente manera: «Mas si se hubieren introducido algunos abusos en estas santas y saludables prácticas, el santo Concilio desea ardientemente que se exterminen de todo punto; de suerte que no se coloquen imágenes algunas de falsos dogmas, ni que den ocasión a los rudos de peligrosos errores». Ibid. 
estrictamente a los textos ortodoxos, para sortear los errores doctrinales: «[...] las imágenes que se formaren, no han de ser como cada vno quisiere, sino es como dixere el Euangelio, sin añadir, ni quitar a lo que dize el texto, o Santos Padres; porque puede ser causa de algunos errores, como si medito en Christo amarrado a la Coluna, no puedo añadir, o quitar a lo que dize el texto que allí pasóm. ${ }^{53}$ Elocuentísima es, en este sentido, la formulación de San Francisco de Borja, en la introducción a su proyecto (inconcluso) de meditaciones sobre las lecturas dominicales del evangelio para acompañar los grabados sobre la Vida de Cristo: "porque la meditación puede engañarnos fácilmente, cuando tomamos una cosa por otra y no seguimos las huellas del Santo Evangelio, al que debemos respetar en los detalles pequeños como en los grandes y no inclinarnos por tanto ni a la izquierda ni a la derecha». ${ }^{54}$ Ello implica que la figura refrena el peligro latente de la imaginación, sometiéndola rigurosamente al mensaje doctrinal.

Afirma Fray Luis de Granada, en el célebre Libro de oración y meditación, que su manual no sólo alimenta la meditación, sino mucho más establece su fin, que no es menos que el «temor de Dios y la enmienda de la vida». Por ello, asevera, "estas catorce meditaciones son otros tantos sermones, en los cuales se da una como batería el corazón humano para rendirlo —en cuanto fuese posible- y entregarlo en manos de su legítimo esposo y verdadero Señor». ${ }^{55}$ Como puede intuirse, las meditaciones secundan, en muchos aspectos, la retórica de la predicación. Cabe destacar que los teóricos modernos de la oratoria sagrada enfatizan a menudo la capacidad de los sermones para mover vehementemente la conciencia del lector y despertar su empatía, de "envolver» a los oyentes en una ola de emociones que, según Barnes-Karol, «impide cualquier tipo de recepción crítica del mensaje verbal». ${ }^{56}$ Estas tesis pueden trasladarse, a mi entender, también a la retórica de la imagen. La figura, en los tratados de meditación, estimula y canaliza la emoción, despierta los afectos de quien mira, dirigiendo y orientando la ponderación del paso meditado. Bartomoleo Cambi, en su Vita dell anima desiderosa, insta al devoto a que repare, durante la consideración de la Pasión de Jesús, en el dolor de su madre, y que se deje llevar, al presenciar la escena, por él. ${ }^{57} \mathrm{El}$ movere, configurado a través de la sinergia entre la imagen y el texto, es decir, entre el artifico retórico y el poder visual de la escena representada, encauza la emoción hacia el ethos cristiano, hacia la vivencia correcta del misterio de la Pasión.

53. Pedro de Villalobos (1675: 127).

54. Citado en Freedberg (2009: 216).

55. Fray Luis de Granada (1994: 22).

56. Barnes-Karol (1992: 57).

57. «Pensa che dolore haurebbe hauto la sua pouera Madre, se ella hauesse visto [...] sanguinosa quella Diuina bocca [...]. Brama con ogni affetto del tuo compassioneuole cuore, di poterli fare almeno tu, in quel caso, qualche seruitio, e col desiderio, \& amoroso affetto del tuo pensiero, desidera d'esserti trouata presente». Cambi (1614: 76). 
A pesar de conceptuarse como un camino conducente hacia la perfecta contemplación, hacia la meta suprema de la vida espiritual, los manuales de meditación - probablemente porque ésta, junto con la oración, representa el primer grado del perfeccionamiento, el de los principiantes-, no suelen exponer principios doctrinales o teologales complejos. La intención de buena parte de ellos es transmitir el ethos elemental del buen cristiano, las pautas de la vida recta y honesta, tal como las sintetizan los diez mandamientos.

La consideración de los dolores de Jesús, declara, por ejemplo, Bartomoleo Cambi, nos enseña a «soportar las injusticias, de buen grado y por el amor de Jesús y de su Madre. Porque de ellos puedes aprender esa doctrina celestial y divina de perdonar, de amar y hacer bien a quien te ofende, de rezar siempre por tus enemigos».58 A su vez, las Meditationi sopra $i$ misterii della passione (1587) de Vincenzo Bruno desvelan el modus operandi de las meditaciones, enfatizando sobremanera la ejemplaridad de las escenas colegidas: al igual que la tabla que Dios le mandó fabricar a Moisés, nosotros también debemos convertirnos, reza el texto, «en piedras vivas», para construir sobre nosotros mismos «el edificio \& casa espiritual». ${ }^{59}$ Cada meditación sobre el misterio debe componerse de tres partes: 1. el ejemplo que debe ser imitado; 2 . la manera en la cual debe interpretarse o considerarse (riguardare) el modelo presentado; 3. el modo en el cual tenemos que imitarlo con nuestras obras. ${ }^{60} \mathrm{La}$ enmienda de la conducta, y con ella el disciplinamiento del devoto y su instrucción en las pautas de la moral cristiana, se sustenta, de este modo, en la emulación de las virtudes de Cristo. Antonio Lacavalleria, en las Meditaciones de la passión y muerte de N. Señor, asevera en el prólogo que «assí como los niños a puro oír las madres, y gorgeas con ellas aprenden a hablar su lengua: assí nosotros morando con nuestro Salvador por la meditación de su Passión, y observando sus palabras, sus acciones, y sus afecciones, aprendemos (mediante sus gracias) a hablar, querer y hazer como él». ${ }^{61} \mathrm{La}$ imitación habilita y facilita la divulgación del dogma, efectuada, paradójicamente, en el fuero más íntimo del creyente, el de su relación personal con el Señor.

58. «Impara hora, anima mia, à sopportar l'ingiurie volontieri per amor del tuo GIESV, e della MADRE sua. Poiche da loro puoi imparare questa Celeste, e sì Diuina dottrina di perdonare, d'amare, di far bene a chi t'offende, e di pregar sempre per gl'inimici tuoi.» Vita dell'anima desiderosa (1614: 337, Canto XIX, Jesús conducido por la calle). Análogamente, en el Canto IV: «Va considerando l'ingiuria grande, che fu fatta al tuo Dio: poiche sì vilmente vien percosso da vn vilissimo huomo, e seruitore. Considera nondimeno l'animo inuitto del tuo GIESV, che non si cangia per questo, o muta nel volto, o dà segno di dolore alcuno, anzi ne mostra allegrezza, e letitia grande; poiche il tutto per amore patiua, e sopportaua [...]. Mira hora, anima mia, quello, che deui far tu, quando sei offesa, percossa, e dispregiata: poiche il tuo DIO, per tuo amore, cotanto per te pate. Vedi quello che deui far tu, vilissima creatura, quando sei inguiriata; poiche il tuo creatore sopporta d'esser così grauemente percosso, da vn vilissimo seruitore». Cambi (1614: 75).

59. Bruno (1587: proemio).

60. Bruno (1587: proemio).

61. Lacavalleria (1660: prólogo $\mathrm{Al}$ Christiano lector). 
En su prólogo al Norte de Ydiotas, Francisco de Monzón consagra un apartado a las motivaciones que le impulsaron a elaborar el texto: «un hombre religioso y virtuoso, estando en una iglesia», cuenta, "puso los ojos en una devota mujer que, estando en oración mental», expresaba por los movimientos de todo su cuerpo los movimientos del alma. La mujer le indica que emplea, para meditar, un librito que se mandó hacer y en el que no hay «escritas lenguas algunas, ni aunque las hubiera yo no las supiera leer, sino que conociendo que soy persona simple, hice pintar aquí unas imágenes para inflamar mi tibieza cuya consideración me mueve a conocerme a mí misma, cuál he sido y cuál soy u cuál seré, y en fin a pensar que es lo que ha de ser de mí». En estas meditaciones, explica, «se engendran en mí las pasiones que vistes en mí». ${ }^{62} \mathrm{El}$ tratado de Monzón fue compuesto en recuerdo y en homenaje a la piadosa seńora; a pesar de ello, no suscribe su modo particular de practicar la meditación. Mientras que la creyente, según sus propias declaraciones, prescinde de la letra y se limita a contemplar las imágenes para inspirar y encender su devoción, Monzón —al igual que los demás tratadistas-, sí considera necesario incluir en su manual componentes textuales. Estos elementos discursivos ejercen de comentario o glosa ineludible: encauzan la mirada del devoto, dirigen la exégesis de la figura y disponen no sólo los aspectos a los que debe atender, sino también los afectos que debe experimentar. Monzón, como cabría esperar, pretende gobernar el curso de la meditación, elaborando para ella una hoja de ruta y un vademécum - en el sentido etimológico de la palabra-, en el que el texto funciona como guardia de la imagen que previene cualquier posible desviación de la emoción, del pensamiento o de la voluntad del practicante. Así, en las declaraciones de la segunda y de la tercera hoja, «de las penalidades que la Muerte trae consigo» y «del juicio divino», respectivamente, los textos que acompañan la imagen exhortan al creyente a renunciar a los pasatiempos y los deleites mundanos; le incitan a una vida casta y exponen algunos puntos centrales de la institución eclesiástica (en el ejemplo citado, determinan el papel del confesor como mediador entre el creyente y el Señor):

«Desta consideración me nacía un temor, representándoseme cómo en la muerte todos mis amigos mundanos y todas mis joyas y todos mis pasatiempos me han de dejar sola en poder y compañía de aquellos viles y hambrientos gusanos, que han de comer aquellas mis delicadas carnes que yo, con tanta curiosidad regalaba, sin me quedar otro fruto sino temer el castigo que mis desordenados deleites merecían». ${ }^{63}$ «Desta consideración me nacía un firme propósito de hacer luego un suficiente escrutinio de todas las culpas que he cometido [...] buscar un sabio y discreto confesor a quien abiertamente se las dijese, para que como ministro de Dios por el poder y llaves que tiene me las perdonase y con su prudencia me diese avisos,

62. Francisco de Monzón, Norte de Ydiotas (1563) en Civil (1995: 146).

63. Francisco de Monzón, Norte de Ydiotas (1563) en Civil (1995: 151). 
como satisfaciendo mis culpas pasadas, no tornase a ofender más a Dios con ellas ni con otras». ${ }^{64}$

Pierre Civil recuerda que los tratados espirituales promueven el ejercicio de la oración en solitario, alentando a «vivir de una manera íntima el comercio con lo divino». ${ }^{65} \mathrm{~A}$ su vez, François Lecercle, al analizar la simbiosis entre la imagen y el texto, sostiene que la adnotatio ofrece información que la imagen en sí no puede proporcionar, porque enfatiza las partes más importantes y esclarece los detalles oscuros o ambiguos. A partir de ese momento, resume Lecercle, «la imagen y su glosa han concluido el trabajo; ahora le toca al lector emprender libremente el vuelo». ${ }^{66}$ En mi opinión, cabría matizar la naturaleza supuestamente libre de ese vuelo de la imaginación y del espíritu. Como podemos colegir del testimonio de Francisco de Monzón, el dogma eclesiástico interviene en el encuentro personal con el Señor de manera muy sutil, pero extraordinariamente vehemente, prescribiendo reglas de la conducta piadosa y disciplinando la vista, la imaginación y la percepción. En ello, los directorios invalidan no sólo la responsabilidad individual del creyente en el desarrollo espiritual, sino también su libertad.

La adnotatio que acompaña el pasaje traza el recorrido de la meditación con tanto rigor y precisión que desviarse del camino marcado es una tarea difícil, o directamente inviable. El poder de la imaginación queda supeditado a los límites determinados por la exégesis del pasaje meditado. La figura, desde esta perspectiva, no proporciona una base sobre la cual el espíritu pueda vagar libremente; al contrario, junto con el texto, controla y guía el curso de la meditación, el encuentro presuntamente libre y creativo del fiel con su Dios. Así, cuando Pierre Civil argumenta que la imagen, en los tratados de meditación, constituye un «lugar común en el que cada cual particulariza su relación con lo transcendente», ${ }^{67}$ deberíamos especificar que este espacio del encuentro con lo numinoso posee, no obstante, confines implacablemente acotados.

La meditación, en conclusión, junto con los demás ejercicios espirituales, representa, por su propia naturaleza, un acto singular de la comunión del alma individual con el Señor. A pesar de ello, los tratados que pretenden inspirarla surgen de una vocación que trasciende lo puramente instructivo. Aspiran, en realidad, a gobernar el acceso hacia la instancia suprema, preservándolo dentro de los paradigmas doctrinales. En consecuencia, la figura, la base imaginativa y visual de la meditación, deviene, junto con el texto que la glosa e interpreta, en un exponente de la propaganda doctrinal, en un instrumento del disciplinamiento

64. Francisco de Monzón, Norte de Ydiotas (1563) en Civil (1995: 155).

65. Civil (1995: 123).

66. Lecercle (1990: 53).

67. Civil (1995: 135). 
religioso y moral. Los tratados de meditación, lejos de propiciar un encuentro personal con el Señor y una vivencia íntima de su gracia, idean un itinerario que regla todos los aspectos de la piedad. Su finalidad central, afirma Pierre Civil, es «dominar los desórdenes de la imaginación». ${ }^{68} \mathrm{Me}$ gustaría subrayar, no obstante, que al someter la imaginación disciplinan también la conciencia de los fieles.

68. Civil (1995: 54). 


\section{Bibliografía}

Alcántara, San Pedro de, Tratado de la oración y meditación, edición preparada por Raquel E. López Ruano, Madrid, Biblioteca de Autores Cristianos, 2012.

Arbiol, Antonio, Desengaños misticos a las almas detenidas, o engañadas en el camino de la perfeccion: Discurrense las mas principales causas y razones, por qué siendo tantas las personas que tratan de oracion mental, son tan pocas las que llegan á ser perfectas, Joseph Carrasco, A. de Sotos, 1784.

Barnes-Karol, Gwendolyn, "Religious Oratory in a Culture of Control», in Culture and Control in Counter-reformation Spain, Anne J. Cruz, Mary Elizabeth Perry (eds.), University of Minnesota Press, 1992.

Bruno, Vincenzo, Meditationi sopra i misterii della passione et resvrrettione di Christo N. S.: Con le figure, \& profetie del vecehio [sic] Testamento, \& con i documenti, che da ciascun passo dell'Euangelio si cauanol Raccolte da diuersi Santi Padri \& da altri diuoti autori, In Genova, Appresso Girolamo Bartoli, 1587.

CAMBi, Bartolomeo (Bartolomeo da Salutio), Vita dell'anima desiderosa di cauar frutto grande dalla Santme. Passione di Giesu Christo, In Roma, nella sta[m] peria della Camera Apostolica, 1614.

Capella, Andreu, Manuale d'escercitii spirituali/del R.P.F. Andrea Capiglia [...] néquali si contengono alcune breui, diuote, \& affettuose meditationi [...] tradotto dallo spagnolo nell'italiano, In Venetia, apresso Pietro Miloco, 1616.

Crvil, Pierre, Image et dévotion dans l'Espagne du XVIe siècle: le traité Norte de ydiotas de Francisco de Monzón: 1563, Paris, Presses de la Sorbonne nouvelle, 1995.

Contemplatio totivs vitae et passionis Domini Nostri Iesv Christi: cum gratia \& priuilegio illustriss. senatus veneti per annos $X$, Venetiis, apud Ioannem Ostaum \& Petrum Valgrisium, 1557.

Coster, Franciscus, Cinquenta meditaciones sobre toda la Passion de Christo Nuestro Señor/ compuestas en latin por el P. Francisco Costero; traduzidas en romance por el padre Diego Mirauete, en Çaragoça, por los herederos de Iuan de Escarrilla, vendese en casa de Iuan de Bonilla, 1601.

Cruz, Fray Juan de la, Diálogo sobre la necesidad de la oración vocal, Madrid, Biblioteca de Autores Cristianos, 1962.

—, Subida al Monte Carmelo, en Obras completas, Madrid, Biblioteca de Autores Cristianos, 1994.

"De invocatione, veneratione, et reliquiis Sanctorum, et sacris imaginibus», en El sacrosanto y ecuménico Concilio de Trento, en la Imprenta Real, 1785.

Dekoninck, Ralph, Ad imaginem: statuts, fonctions et usages de l'image dans la littérature spirituelle jésuite du XVIIe siècle, Librairie Droz, 2005.

Freedberg, David, El poder de las imágenes. Estudios sobre la historia y la teoría de la respuesta, Madrid, Cátedra, 2009. 
Granada, Fray Luis de, Manual de oraciones y espirituales ejercicios, en Obras completas, III, edición y nota crítica Álvaro Huerga, Fundación universitaria española, Madrid, 1994.

Grunebaum, Gustave E. von, «Parallelism, Convergence, and Influence in the Relations of Arab and Byzantine Philosophy, Literature, and Piety», Dumbarton Oaks Papers, Vol. 18. (1964), 89-111.

Guigo II, Scala claustralium, en Lettre sur la vie contemplative: l'échelle des moines. Douze méditations. Paris, Éditions du Cerf, 1970.

Lacavalleria, Antonio, Meditaciones de la passion y mverte de N. Señor y Redemptor Iesu Christo, en Barcelona, 1660.

Lecercle, F., «Image et méditation. Sur quelques recueils de méditations illustrés de la fin du XVI ${ }^{\mathrm{e}}$ siècle», en La Méditation en prose à la Renaissance, Cahiers, V. L. Saulnier, 1990, p. 45-58.

Madre De Dios, Diego de la, Arte mistica, especulativa, y practica, reducida a breve metodo, dividida en dos tratados: en el primero, se ponen los principales puntos de la Mistica Theologia Especulativa, y los medios para caminar, y llegar à la perfeccion Christiana, y Religiosa, en el segundo, las mas principales Meditaciones, que conducen à la practica, y exercicio de la Oracion Mental, Salamanca, 1713.

Mira Gómez de Mercado, María Dolores, Actualización, estudio y edición del Diálogo sobre la necesidad de la oración vocal, obras virtuosas y santas ceremonias de fray Juan de la Cruz (1555), Universidad de Almería, 2012.

Molina, Antonio de, Exercicios espiritvales mvy provechosos para personas ocupadas, desseosas de su saluacion/ compuestos por el P. Don Antonio de Molina, En Barcelona, en casa de Sebastian y Iayme Matevad, a costa de Miguel Gracian, 1635.

Monzón, Francisco de, Norte de ydiotas compuesto y reuisto por el doctor Francisco de Móçon, a donde se trata vn exercicio muy spiritual y prouechoso, en Lixboa, en casa de Ioannes Blauio de Colonia, 1563.

-, Norte de Ydiotas. Compuesto y revisto por el Doctor Francisco de Monzón. Adonde se trata un ejercicio muy epiritual y provechoso, Lisboa, 1563, edición incluida en Pierre Civil: Image et dévotion dans l'Espagne du XVI siècle: le traité Norte de ydiotas de Francisco de Monzón: 1563, Paris, Presses de la Sorbonne nouvelle, 1995.

Mujica Pinilla, Ramón, Rosa Limensis: mistica, politica e iconografía en torno a la patrona de América, Fondo de Cultura Económica, 2005.

Palomo, Federico, «Disciplina christiana. Apuntes historiográficos en torno a la disciplina y el disciplinamiento social como categorías de la historia religiosa de la alta edad moderna», Cuadernos de Historia Moderna, 18 (1997) 119-136.

-, «Limosnas impresas. Escritos e imágenes en las prácticas misioneras de interior en la península Ibérica (siglos XVI-XVIII)», Manuscrits: revista d'història moderna, 25 (2007) 239-265. 
PInelli, Luca, Libretto di brevi meditationi del Santiss. Sacramento e della preparatione alla sacra communione, Napoli, appresso Gio. Giacomo Carlino et Antonio Pace, 1598.

Puente, Luis de, Meditaciones de los mysterios de nuestra santa fe con la práctica de la oración mental sobre ellos, Barcelona, Lucas Sánchez, 1609.

SERÉs, Guillermo, Literatura espiritual en los siglos de Oro, Madrid, Laberinto, 2003.

TAusiet, María, «Espíritus libres: el alumbradismo y Miguel Servet», Hispania Sacra, LXV 131, enero-junio (2013) 73-102.

VEGA, María José, «Introducción», en María José Vega, Iveta Nakládalová (eds.), Lectura y culpa en el siglo XVI, Reading and Guilt in the $16^{\text {th }}$ Century, Universitat Autònoma de Barcelona, Bellaterra, 2012.

Villacastín, Tomás de, Manual de exercicios espirituales para tener oracion mentallcompuesto por Thomas de Villacastin, Barcelona, por Pablo Campins, 1714.

Villalobos, Pedro de, Tratado en que se impugna el nueuo modo de oracion de contemplacion de fe, Roque Rico de Miranda, 1675. 
